\title{
Prisen for at være loyal allieret
}

\section{Torben Krogh}

\section{Den moralske begrundelse for dansk deltagelse i Irak-krigen har været svært forenelig med de mid- ler, som vor store allierede har taget i anvendelse}

Sandheden var ikke krigens første offer i Irak. Den blev ofret forinden af de kræfter i præsident George W. Bushs administration, der nærede et brændende ønske om at invadere Saddam Husseins Irak for at fjerne denne, en af sin samtids mest brutale diktatorer, for at eliminere truslen imod Iraks nabolande og for at få kontrol over landets enorme oliereserver. Trods advarsler fra adskillige medlemmer af det Nationale Sikkerhedsråd var det vicepræsident Dick Cheney, forsvarsminister Donald Rumsfeld og viceforsvarsminister Paul Wolfowitz, der vandt præsidentens øre. Deres vigtigste argumenter var, at Saddam Hussein var i besiddelse af masseødelæggelsesvåben og derfor udgjorde en fare for regionen, at han var bagmand for international terrorisme, og at en sejrrig krig ville udløse demokrati ikke blot i Irak, men virke med en domino-effekt i andre autokratisk styrede mellemøstlige stater.

De to påstande viste sig at være decideret usande. Og forventningerne er mildt sagt ikke blevet indfriet. De demokratiske kræfter, Wolfowitz lovede ville dukke op over alt, så snart Saddam Hussein var fjernet, var langt færre og har hidtil været magtesløse over for de grupper, der forsøger at udkæmpe den politiske magtkamp med våben. I det omfang, Cheney, Rumsfeld og Wolfowitz selv troede på de argumenter, de brugte under de interne rådslagninger, har det vist sig, at de var ofre for en illusion.

Intet af dette kunne statsminister Anders Fogh Rasmussen vide, da han tidligt i 2003 besluttede, at Danmark skulle være en del af 'de villiges koalition'. Han måtte formode, at der lå solid vægt bag Washingtons udsagn om i hvert fald masseøde- 


\section{TORBEN KROGH}

læggelsesvåbnene. Dertil kom Saddam Husseins åbenlyse disrespekt for de resolutioner, der var vedtaget af FN's sikkerhedsråd, og hans legen kispus med FN's våbeninspektører under ledelse af Hans Blix. I modsat retning trak dog netop våbeninspektørens appel om at få mere tid til sit arbejde og det faktum, at der ikke lå noget klart FN-mandat til grund for den invasion, amerikanerne planlagde.

\section{Idealisme som drivkraft}

Når statsministeren valgte at følge USA ind i krigen på dette grundlag, kan det ikke forklares ud fra nogen klassisk dansk geo- eller realpolitisk interesse. Danmark militære deltagelse bragte os på kant med det øvrige Norden, med store, toneangivende EU-lande som Tyskland og Frankrig, og med den store nabo Rusland. Der var hverken nære eller fjerne sikkerhedsinteresser på spil for Danmark i højere grad end for noget andet europæisk land.

Anders Fogh Rasmussens motivation var derfor en anden, og der er næppe nogen bedre forklaring, end at han var drevet af en form for idealisme. Han ønskede at vise loyalitet over for den store allierede. Han har aldrig lagt skjul på sin beundring for USA, og han mener, at den amerikanske indsats under Anden Verdenskrig stadig er en gangbar begrundelse for at vise USA særlig taknemmelighed. Indenrigs- politisk stod han stærkt nok til at sætte sin vilje igennem, selv om der var betydelig skepsis, ikke mindst i Udenrigsministeriet.

Idealisme er imidlertid tæt forbundet med moral. Idealer må nødvendigvis udspringe af en moralsk betinget skelnen mellem godt og ondt. Her var det naturligvis ikke svært at placere Saddam Hussein. Men selv om han entydigt repræsenterede det onde, var det jo ikke nødvendigvis ensbetydende med, at USA ubetinget stod for det gode. Sådan fremstillede Bush-regeringen ganske vist konflikten i dens mest forenklede form. Men det behøver en dansk regeringschef ikke uden videre tage for gode varer.

Under alle omstændigheder tyder meget på, at det idealistiske hensyn vejede tungt for statsministeren. Han førte Danmark ind i den første angrebskrig, vi har medvirket til i flere århundreder. Han gjorde det på grundlag af et spinkelt flertal i Folketinget, hvad der også er helt usædvanligt i en sådan sammenhæng. Det var endnu et tegn på, hvor stærkt det lå ham på sinde at Danmark viste vidtrækkende loyalitet over for USA.

Den idealistiske tilgang blev også afspejlet i de officielle begrundelser for den danske deltagelse. De danske tropper var i Irak for at bidrage til landets demokratiske opbygning. Det var i sig selv en god og nødvendig gerning, at Saddam Hussein blev fjernet. Som statsministeren gang på 
gang retorisk spurgte sine kritikere: Foretrak de måske, at diktatoren var forblevet ved magten? Hvad de naturligvis ikke gjorde.

Ved at skubbe de ideale og moralske hensyn i forgrunden, bevægede Anders Fogh Rasmussen sig imidlertid skridt for skridt ud i en stadig mere åbenbar selvmodsigelse. For det var bestemt ikke hverken idealer eller høje moralske krav, der styrede hans politik over for hverken USA eller den hjemlige opposition.

\section{Afvisningens politik}

For at tage et nyligt eksempel, der omfatter begge disse aspekter. Da det kom frem, at CIA havde gennemført et stort antal hemmelige fangetransporter i Europa, blev også Danmark inddraget. I første omgang hed det sig, at der siden 2001 havde været otte landinger i danske lufthavne af fly, som blev sat i forbindelse med disse transporter. I oktober oplyste transportminister Flemming Hansen så i et svar til Folketinget, at der i samme periode havde været yderligere 37 landinger af fly, som i hvert fald Amnesty International sætter i forbindelse med den amerikanske efterretningstjeneste.

Har noget sådant fundet sted, vil det være i åbenlys strid med det danske forbud mod sådanne flyvninger. To gange inden transportministerens svar havde Danmark gjort det klart over for USA, at man forventer, at CIA respekterer dansk lovgivning
- hvad amerikanerne bedyrede, at de gør. Og det var tilstrækkeligt for statsministeren. Oppositionens krav om at få denne sag undersøgt til bunds, blev som alle lignende krav igennem de sidste fire-fem år afvist. Anders Fogh Rasmussen sagde oven i købet, at han ikke havde hørt noget om denne sag og derfor ikke ville tage stilling til den.

Den radikale Morten $\emptyset_{\text {stergaard }}$ satte ord på oppositionens forundring: "Regeringen startede med overhovedet ikke at ville diskutere det her tema og kaldte det løse rygter. Men nu har USA indrømmet, at der eksisterer hemmelige fængsler rundt omkring i verden. Derfor er det påfaldende, at regeringen bliver ved med at afvise en sådan undersøgelse. Når amerikanerne kan indrømme det, hvorfor kan den danske regering så ikke gøre det?”

Det kunne - eller rettere ville den ikke, fordi loyaliteten over for Bush-regeringen hele vejen igennem har været styrende for dens handlinger. Det har igen ført til, at den danske regering har afstået fra at kritisere amerikanske beslutninger og gerninger, selv om de strider imod centrale principper i den danske udenrigspolitik.

\section{Undergravet retsorden}

Som demokratisk småstat er det i Danmarks indlysende interesse, at den internationale retsorden bliver så stærk og bindende som muligt. 


\section{TORBEN KROGH}

Det er et standpunkt, som også den nuværende regering har givet udtryk for gang på gang. Men bortset fra nogle få forsigtige beklagelser er denne holdning blevet skudt til side i forhold til Bush-regeringen.

Statsministeren har udtrykt stærk vrede over de dokumenterede mishandlinger af fanger i både Irak og Afghanistan. Men omhyggeligt har han undgået at kæde torturen sammen med den officielle amerikanske politik. Ganske som regeringen i Washington finder han det mest bekvemt, hvis overgreb kan isoleres til at være underordnede soldaters individuelle misgerninger.

At det så langt fra er tilfældet, burde have stået klart allerede tidligt $\mathrm{i}$ 2002, da fremtrædende repræsentanter for Bush-administrationen fastslog, at i kampen mod terror kunne det være nødvendigt at bevæge sig ud over de rammer, der er udstukket i Geneve-konventionen. Som forhenværende major i Forsvarets Efterretningstjeneste, Stephen Egede Glahn, skrev 21. februar 2007 i Information: "De forbehold og deraf følgende manglende retningslinjer for behandlingen af fanger skabte en glidebane for mishandling, nedværdigende behandling og tortur, som vil få langtrækkende konsekvenser for ofrene og deres børn, ikke mindst i form af et had, som ikke tegner godt for fremtiden. Der bliver noget at rette op på for en anden amerikansk administration."

Men der havde også været noget at gøre indsigelser imod for en dansk regering. Topledelsen i verdens eneste supermagt proklamerede åbenlyst, at den ikke agtede at respektere eksisterende international retsorden. Netop det aspekt blev fremdraget af to Spiegel-journalister, da de for nylig (Der Spiegel 29/1 2007) interviewede den tidligere CIA-chef for Europa, Tyler Drumheller. Han bliver spurgt om bortførelsen af mistænkte islamiske ekstremister og bekræfter, at han selv var involveret i denne aktivitet. Han oplyser, at han havde meget blandede følelser om hele denne sag. Men han kan se formålet med bortførelserne, "hvis de gennemføres korrekt". Spiegel-journalisterne anfører, at det vel i det mindste må indebære, at målet for sådanne bortførelser ikke er uskyldige mennesker. Drumheller svarer:

"Det var vicepræsident Dick Cheney, der talte om 'den mørke side', vi måtte mobilisere. Da han udtalte dette, formulerede han en politik, der reelt betød 'gå i gang og få ram på dem'. Hans bemærkninger afspejlede regeringens underliggende tilgang, der grundlæggende var at slippe militæret og tjenesten (CIA) løs og lade dem betale for konsekvenserne af enhver ulykkelig - eller ulovlig - hændelse."

Nok har Cheney hele vejen igennem været en af de mest militante høge i Bush-administrationen. Men han har ikke udtalt sig på egne vegne. Der har været - og er - dækning 
for hans holdning blandt dem, der i disse år bestemmer USA's udenrigsog militærpolitik.

\section{Amerikansk enegang}

En anden afspejling af dette krav om at være hævet over den internationale retsorden, som andre lande formodes at respektere, er den amerikanske afvisning af at acceptere retningslinjerne for Den Internationale Krigsforbryderdomstol. Det er helt i orden, at mistænkte fra fx Balkan og Afrika stilles for denne domstol. Men er der tale om amerikanske statsborgere, tolereres det ikke. Over for den stærke diplomatiske pression, der her blev udøvet, stod Danmark fast sammen med de øvrige EU-lande. Men den officielle afstandtagen fra USA's magtfuldkomne enegang var spag.

Det samme kan siges om regeringens reaktioner på de forhold, der hersker i Guantanamo-lejren. Så længe en dansk statsborger sad interneret, havde denne sag en vis interesse. Men de danske krav til USA var beskedent og diskret formuleret i sammenligning med fx de svenske. Det blev begrundet med, at stille diplomati ville øge chancerne for at få danskeren løsladt. Det skete da også, men svenskerne blev nu ligeledes udleveret til eventuel rettergang i deres eget land.

Dette begreb eksisterer ikke for de mennesker, der nu på femte år befinder sig i lejren. Det er ved en lov, gennemført efter præsidentens stærke ønske, blevet fastslået, at de ikke kan gøre krav på normal retsbeskyttelse. De har ikke krav på at blive stillet for en dommer eller opnå advokatbistand. Begrundelsen er, at de ikke er amerikanske statsborgere, og at de er mistænkt for at være 'fjendtlige kombattanter' - et begreb opfundet til lejligheden for at komme uden om de rettigheder egentlige krigsfanger har krav på.

Beretningerne om grov mishandling og dybt nedværdigende behandling af fangerne i Guantanamo har været mange. Alligevel vakte det opsigt, da en så officiel og autoritativ kilde som forbundspolitiet FBI for nylig frigav dokumenter om FBIagenters iagttagelser i Guantanamo. De kunne fortælle om en hel vifte af torturlignende foranstaltninger. Reelt har regeringen i Washington intet foretaget sig i den anledning.

\section{Dansk tilpasning}

Flere facetter kunne føjes til dette billede af den store allierede, som den danske regering - og i særdeleshed statsministeren - har valgt at vise nærmest ubetinget loyalitet. Det er et billede, der gør det svært at fastholde forestillingen om, at vi her har at gøre med en krig mellem 'det gode og det onde'. De primære ofre er selvfølgelig indbyggerne i de krigshærgede lande og de millioner, der er flygtet. Men langt mere er blevet ofret. Bush-regeringens egen- 


\section{TORBEN KROGH}

rådige fremfærd har sat den internationale retsorden under pres. Argumentet om, at international terrorisme i endnu højere grad kan undergrave denne retsorden, er uimodsigeligt. Men det burde ikke være en gyldig begrundelse for - fra en helt anden indfaldsvinkel - at bidrage til en sådan proces. Tværtimod burde svaret på terrorismens trussel bestå $\mathrm{i}$ at styrke denne retsorden.

Regeringens svar vil utvivlsomt være, at det så sandelig også er, hvad den arbejder for. Problemet er blot, at en sådan forsikring svækkes af den tætte alliance med en supermagt, der gennemfører ulovlige bortførelser, skyder en så vigtig aftale som Geneve-konventionen til side, internerer mennesker på ubestemt tid under de mest nedværdigende forhold og uden adgang til at blive retsforfulgt, og som forbeholder sig ret til at handle på tværs af internationale retsnormer, den ikke bryder sig om.

En sådan allieret må være svær for en statsminister, der ud fra idealistiske forestillinger og moralske begrundelser stillede Danmark op i rækken af 'villige allierede'. Men de forløbne fire år har vist, at han har stået ved dette valg. Både idealisme, moral og primære danske interesser er blevet kørt ud på et sidespor til fordel for en pragmatisk, tilpasningsdygtig politik over for den amerikanske præsident.

At de danske styrker i Irak kan trækkes ud fra august i år, er utvivl- somt en lettelse for Anders Fogh Rasmussen. Men tilbagetrækningen ændrer intet ved hans fundamentale holdning til USA, uanset hvem der er supermagtens præsident.

Selv om beslutningen om at hente tropperne hjem især blev forhandlet med den britiske premierminister Tony Blair, lagde statsministeren vægt på omgående at oplyse, at han også havde været i telefonisk forbindelse med George W. Bush, der havde takket danskerne for deres indsats og udtrykt glæde over, at tilstandene i det sydlige Irak nu var sådan, at det om nogle måneder er muligt at overlade ansvaret til de irakiske sikkerhedsstyrker.

Tilbage står, at Danmark har været - og i et vist omfang stadig vil være - aktiv deltager i en krig, der både faktuelt og moralsk blev indledt på et grundlag, der siden har vist sig at være ganske uholdbart. Der er ingen grund til at betvivle, at statsministeren mente, hvad han sagde, da han lod Danmark tilslutte sig de krigsførende magter.

Men siden har han haft lejlighed til at konstatere, at der var langt mellem de proklamerede idealer og de faktiske forhold. Hans problem er, at han ikke desto mindre hele vejen igennem har fastholdt en stort set ukritisk loyalitet over for den store allierede.

Torben Krogh er journalist og politisk reporter ved Information. 